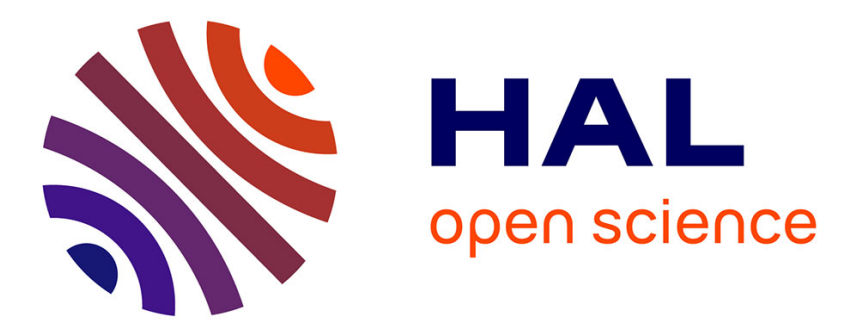

\title{
An immunomarking method to determine the foraging patterns of Osmia cornifrons and resulting fruit set in a cherry orchard
}

\author{
David Biddinger, Neelendra Joshi, Edwin Rajotte, Noemi Halbrendt, \\ Cassandra Pulig, Kusum Naithani, Mace Vaughan
}

\section{To cite this version:}

David Biddinger, Neelendra Joshi, Edwin Rajotte, Noemi Halbrendt, Cassandra Pulig, et al.. An immunomarking method to determine the foraging patterns of Osmia cornifrons and resulting fruit set in a cherry orchard. Apidologie, 2013, 44 (6), pp.738-749. 10.1007/s13592-013-0221-x . hal01201342

\section{HAL Id: hal-01201342 \\ https://hal.science/hal-01201342}

Submitted on 17 Sep 2015

HAL is a multi-disciplinary open access archive for the deposit and dissemination of scientific research documents, whether they are published or not. The documents may come from teaching and research institutions in France or abroad, or from public or private research centers.
L'archive ouverte pluridisciplinaire HAL, est destinée au dépôt et à la diffusion de documents scientifiques de niveau recherche, publiés ou non, émanant des établissements d'enseignement et de recherche français ou étrangers, des laboratoires publics ou privés. 


\title{
An immunomarking method to determine the foraging patterns of Osmia cornifrons and resulting fruit set in a cherry orchard
}

\author{
David J. BidDINGER ${ }^{1,2}$, Neelendra K. Joshi ${ }^{1,2}$, Edwin G. RaJotte ${ }^{2}$, \\ Noemi O. Halbrendt ${ }^{3}$, Cassandra Pulig ${ }^{1}$, Kusum J. Naithani ${ }^{4}$, Mace Vaughan ${ }^{5}$ \\ ${ }^{1}$ Fruit Research and Extension Center, Entomology, Pennsylvania State University, 290 University Dr, Biglerville \\ 17307, PA, USA \\ ${ }^{2}$ Department of Entomology, Pennsylvania State University, 501 ASI Building, University Park 16802, PA, USA \\ ${ }^{3}$ Fruit Research and Extension Center, Plant Pathology, Pennsylvania State University, \\ 290 University Dr, Biglerville 17307, PA, USA \\ ${ }^{4}$ Department of Geography and Intercollege Graduate Degree Program in Ecology, Pennsylvania State University, \\ University Park 16802, PA, USA \\ ${ }^{5}$ Xerces Society for Invertebrate Conservation, 628 NE Broadway Ste 200, Portland 97232, OR, USA
}

Received 11 June 2012 - Revised 15 May 2013 - Accepted 27 June 2013

\begin{abstract}
The foraging patterns of Osmia cornifrons (Radoszkowski) (Megachilidae, Hymenoptera) were determined with an immunomarking method and correlated with fruit set in a commercial tart cherry orchard in Pennsylvania. Adults of $O$. cornifrons were self-marked with chicken egg-white protein powder from a dispenser nest box placed at the center of the study orchard at early bloom. Flower samples were collected from randomly selected trees $(n=30)$ located at different distances from the nest box. Flowers were analyzed for the presence of immunomarker protein with enzyme-linked immunosorbent assay. Foraging patterns were determined by measuring the distance and direction of marked flowers from the nest box. While marked flowers were found out to $55 \mathrm{~m}$ (maximum distance sampled), most marked flowers were found within $35 \mathrm{~m}$ from the nest and the percentage of marked flowers declined rapidly beyond that distance. Fruit density per limb cross-sectional area $\left(\mathrm{cm}^{2}\right)$ in the study orchard was significantly higher than in the orchard without $O$. cornifrons, indicating the value of $O$. cornifrons as pollinators in increasing fruit yield in tart cherries.
\end{abstract}

immunomarking / foraging patterns / Osmia cornifrons / self-marking procedure / pollination / pollinator / mason bees

\section{INTRODUCTION}

Osmia cornifrons (Radoszkowski) (Megachilidae, Hymenoptera), commonly known as the hornfaced bee or the Japanese orchard bee, is a univoltine and solitary bee species. It is a manageable and commercially available alternative pollinator of rosaceous tree fruit species (Bosch and Kemp

Corresponding author: D.J. Biddinger, djb134@psu.edu; N.K. Joshi, nkj105@psu.edu

Manuscript editor: Peter Rosenkranz
2002; Mader et al. 2010; Maeta and Kitamura 1974; Sekita and Yamada 1993). In Japan, the development of $O$. cornifrons as a fruit pollinator started in the 1930s and increased in use from $10 \%$ of the total apple production area in 1981 to over $80 \%$ by 1996 (Maeta 1990; Sekita et al. 1996; Batra 1998). Introduced in the eastern United States from Japan in 1977 (Batra 1979, 1998) as an orchard pollinator, it has become naturalized in several states including Pennsylvania where natural emergence coincides with red maple and apricot bloom and continues through the end of 
apple bloom 3-4 weeks later (Biddinger et al. 2009a; Biddinger et al. 2011a, 2011b). It has more recently been introduced as a commercial pollinator of fruit in Korea and China (Xu et al. 1995). While this species nests in abandoned wood beetle galleries and other cavities in the wild, $O$. cornifrons can also be managed by providing nest boxes full of nest cavities (e.g., cardboard tubes, bamboo segments, pre-drilled wooden blocks, etc.) (Mader et al. 2010). These nest boxes can be held at cold temperatures to delay adult emergence and synchronize with later flowering target crops, such as apple and blueberry that bloom towards the end of the natural emergence period (Bosch et al. 2008; Mader et al. 2010).

The maximum distance from which nesting bees are able to find their nests, also known as homing range, is believed to be a good estimate of a bee's maximum foraging range and potential habitat size (Gathmann and Tscharntke 2002; Greenleaf et al. 2007; Guedot et al. 2009). However, homing range depends on various factors, including availability of floral resources. In the case of $O$. cornifrons, it was estimated to be approximately $500 \mathrm{~m}$ (Guedot et al. 2009) with effective pollination range of only 40 to $60 \mathrm{~m}$ in large orchards (Maeta and Kitamura 1974; Kitamura and Maeta 1969; Yamada et al. 1971). For a similar orchard pollinator, Osmia cornuta, adult bees foraged up to $400 \mathrm{~m}$ from the nesting sites (Maccagnani et al. 2003). In a similar study on $O$. cornuta foraging in a pear orchard, over $75 \%$ of samples of $O$. cornuta had pear pollen in the fecal matter (Monzon et al. 2004), suggesting strong foraging activity within the orchard where nesting shelters were placed. In the case of $O$. cornifrons, in spite of considerable research in Japan on its ecology and management in commercial tree fruit orchards (Yamada et al. 1971; Yamada et al. 1984, Maeta 1978, Maeta and Kitamura 1974), its foraging behavior in the fruit growing regions of the eastern USA or elsewhere is not well known. Estimating foraging distance of $O$. cornifrons in tree fruit species (e.g., cherry and apple) and their impact on fruit set could be helpful in determining nest density and placement of managed nest aggregations (multiple nest blocks in a nest shelter) in commercial orchards, as well as the pollination limitations of wild populations flying into commercial orchards from adjacent habitat.

In the past, researchers have used a variety of techniques to quantify the movement of different insect species. Most of these techniques (e.g., mark-release-recapture using trace elements) had numerous drawbacks, particularly related to their high cost of implementation or extensive technical expertise needed for their operation (Akey et al. 1991). Moreover, some of these techniques require capturing and killing foraging bees. In large colonies of social bees using non-reproductive workers as foragers consequences to the colony are likely insignificant, but the capturing and killing of foraging solitary bee females also means killing potential offspring. Recently, a highly effective protein-based marking (immunomarking) method for studying dispersal of insect fauna was developed (Hagler et al. 1992; Hagler 1997; Hagler and Jackson 1998). In this method, experimental insects or their habitat were marked with a vertebrate-specific protein marker, and the recaptured insects were examined for the presence of the marker antibodies using a highly sensitive enzymelinked immunosorbent assay (ELISA) procedure. In the early phase of research and development of this marking technique, costly rabbit $\operatorname{IgG}$ and chicken $\operatorname{IgG}$ proteins were widely used as marker proteins in mark-release-recapture studies (Hagler et al. 1992; Hagler 1997; Blackmer et al. 2004; Hagler and Naranjo 2004; Buczkowski and Bennett 2006). These markers were costly, however, so recently, inexpensive protein markers such as chicken egg whites, bovine milk protein, and soy milk protein have been employed for mark-release-recapture studies (Jones et al. 2006; Hagler and Jones 2010).

The immunomarking (protein-based) markrelease-recapture method has been used in determining dispersal and movement of a wide range of insect pests of fruit crops including adult pear psylla (Cacopsylla pyricola), codling moth (Cydia pomonella) (Jones et al. 2006), and glassy-winged sharpshooter, Homalodisca vitripennis (Blackmer et al. 2006). 
Hagler et al. (2011a, 2011b) used a self-marking mechanism to apply unique fluorescent powders or protein markers to Apis mellifera as they left the hive to determine foraging ranges by capturing individual bees. Our study used this technique to mark $O$. cornifrons females as they foraged from a nest shelter placed in the center of a tart cherry orchard. $O$. cornifrons are much more wary and energetic in the field than A. mellifera (Biddinger, personal observation) and are capable of visiting up to 15 flowers per minute (Maeta and Kitamura 1974). This makes them difficult to capture in the field. So, rather than capturing the bees, we collected flowers at set distances from the nest box to test for the presence of the marker to see where the bees had visited. By looking at the percentage of flowers marked, we hoped to quantify pollination range limits at which a single nest box of $O$. cornifrons could effectively pollinate the crop (without killing the bees or disrupting their behavior).

The information related to foraging ranges of $O$. cornifrons is critical in developing management guidelines (e.g., how far apart to place nests) for using $O$. cornifrons as a managed pollinator of tree fruits. $O$. cornifrons is abundant in forest edges adjacent to fruit orchards in some parts of Pennsylvania and many fruit growers are relying on it and other unmanaged populations of on nonApis bees to pollinate cherries, apples, and other tree fruit (Ritz et al. 2012; Biddinger et al. 2010, 2011a; Joshi et al. 2011). Understanding its foraging range in flowering orchards is also necessary to understand how much and how far pollination services may be provided by bees nesting in wooded areas adjacent to orchards.

Specifically, we investigated (1) the appropriateness of a self-marking system for $O$. cornifrons; (2) the relationship between the proportion of immunomarked flowers, distance and direction from the nest and, thus, the foraging patterns of $O$. cornifrons in a tart cherry orchard during early stage of bloom; and (3) the relationship between the proportion of marked flower samples and the fruit density per limb crosssectional area $\left(\mathrm{cm}^{2}\right)$ of sampled trees as a measure of yield over the marked foraging area and as a measure of pollination efficiency when these trees were compared to cherry trees of a control orchard block without $O$. cornifrons.

\section{MATERIALS AND METHODS}

\subsection{Study orchards}

Field and laboratory studies were conducted in Adams County, Pennsylvania in a commercial and a research tart cherry, Prunus cerasus L., orchard located adjacent to and on the Pennsylvania State University Fruit Research and Extension Center during the 2011 growing season. The nest box with the protein marker dispenser was placed in a 7.4-ha commercial Montmorency cherry orchard on Mahaleb rootstock that was planted in 2004 at a spacing of $4.9 \mathrm{~m}$ by $7.2 \mathrm{~m}$ ( 287 trees/ha). A 0.25 -ha control orchard planted in 2006 with the same tart cherry variety, on the same rootstock and with the same row spacing was located on the Penn State Fruit Research and Extension Center. The control block was $600 \mathrm{~m}$ away from the commercial orchard and from the nearest Osmia nesting habitat. Timed counts (30 min) of bees visiting cherry flowers in each cherry block found equivalent levels of $A$. mellifera in both blocks with commercial hives located equidistant from both blocks. The timed counts of bees were performed by randomly walking through the whole area of the study and control orchard blocks. In the year of the study, honey bees were not brought into the station until after cherry bloom for the beginning of apple bloom, so neither cherry block had stocked honey bees. Other pollinator species (several species of Andrena) were found infrequently along the borders of the commercial cherry block, but not in the control block on the research station. During the study period, meteorological data (wind speed, wind direction, and air temperature) were recorded by a Weather Station of the Penn State Fruit Research and Extension Center located adjacent to the study orchard.

\subsection{Study insects}

The overwintering adults of $O$. cornifrons $(1,200$ loose cocoons extracted from nest tubes of which a subsample reared to eclosion in cages, indicated a 59:41 ratio of males to females, and about $10 \%$ mortality in the 
cocoon phase) used in this study were obtained by trapnesting wild populations of $O$. cornifrons from several nearby Adams County orchards the previous spring using Osmia BinderBoards ${ }^{\circledR}$ (Pollinator Paradise, Parma, ID, USA). Binderboards ${ }^{\circledR}$ are laminated wooden blocks with 49 holes $(8 \mathrm{~mm}$ diameter and $150 \mathrm{~mm}$ depth) lined with paper straws. The nests were left in the orchards all season from mid-April through October and then gathered into a screened insectarium in October to overwinter under ambient conditions. The number of $O$. cornifrons released for this study was based on recommended number of females needed to pollinate 1 ha of apples in Japan (Yamada et al. 1971).

\subsection{Nest placements}

A nest box with dispenser (for the powdery chicken egg white protein formulation), previously tested to use $O$. cornifrons as a delivery system for a powdered formulation of Bacillus subtillus for the biological control of fireblight in apple and pear orchards (Biddinger et al. 2009b, 2010), allowed the exiting bees to self-mark (Figure 1). This simple wooden structure was modified from a design by Maccagnani et al. (2006) who used it to test fireblight biological control using Bombus as the dispersing agent, but we modified it to accommodate the much smaller $O$. cornifrons. Three empty BinderBoard ${ }^{\circledR}$ wooden blocks, each with 49 holes $(8 \mathrm{~mm})$ lined with paper straws for nesting were placed within the main body of the nest dispenser. Loose $O$. cornifrons overwintering cocoons $(n=1,200)$ were placed inside the nest box shelter in two emergence cardboard boxes each with two $10 \mathrm{~mm}$ emergence holes. A transparent plastic exit ramp with a removable piece of 10-mm-thick plexiglass with six shallow channels (4 mm deep) was loaded manually with the fine egg white powder in the early morning before flight and again at mid-day. To force the bees to move through the channels and pick up the egg white powder rather than directly flying out of the ramp opening, a piece of clear acetate, used for overhead projectors, was taped over the opening, sloping down to the edge of the ramp to force bees to exit through the constricted opening formed by the acetate and grooved plexiglass plate. This plexiglass plate could be moved freely in and out of a groove formed by aluminum channel plates on each side and rested upon another piece

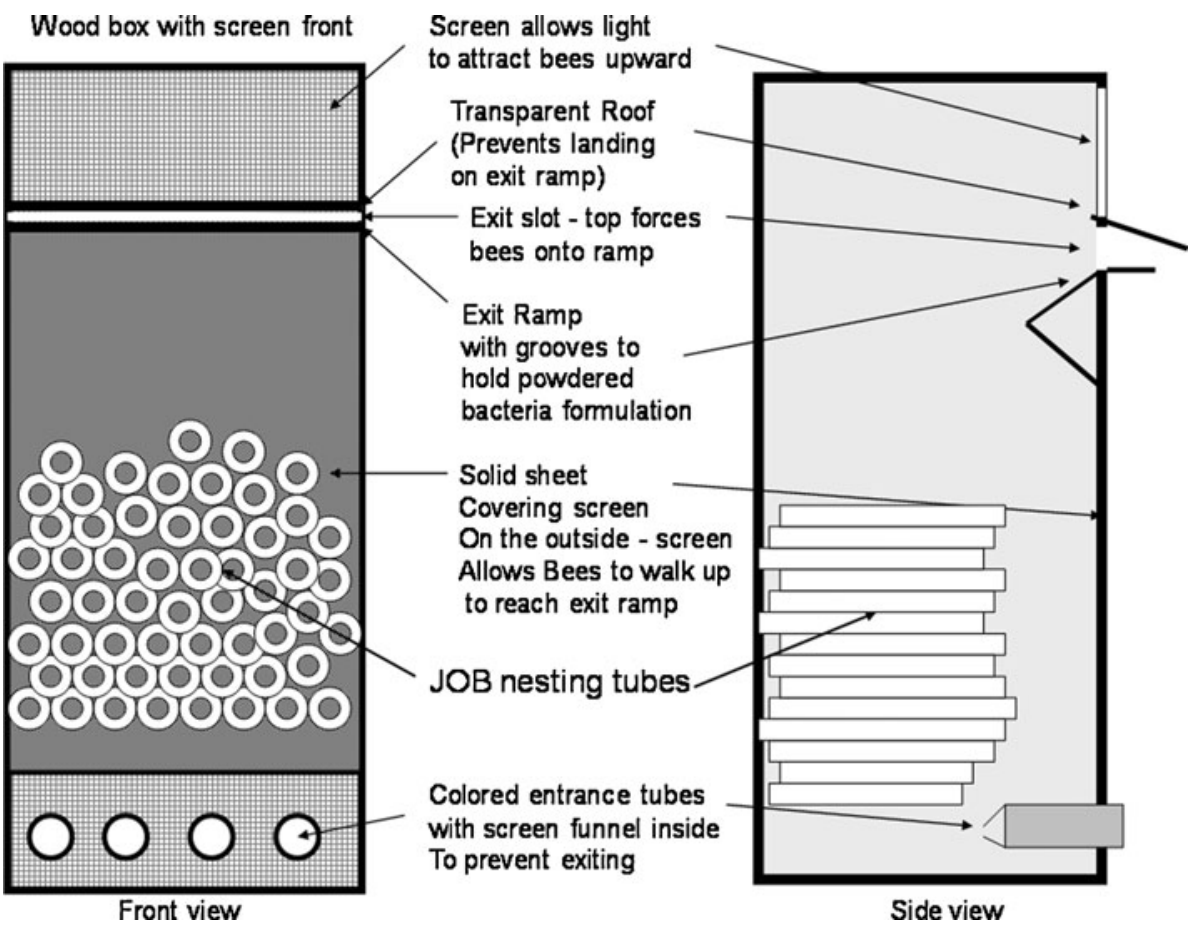

Figure 1. Osmia nest box used in the study (Source: Penn Fruit News). JOB Japanese orchard bee (O. cornifrons). 
of plexiglass of the same dimensions that was permanently affixed to the outside of the nest box. This allowed quick and easy removal and filling of the grooves with the egg white powder without disturbing the bees. The entrance tubes at the bottom of the nest box were made of PVC tubing with an inside diameter of $9 \mathrm{~mm}$ and were marked with different dark colors to help females "remember" the correct entrance hole from their initial orientation flight and return directly to a specific tube opening. In the fireblight biocontrol study, Biddinger et al. (2010) observed that $95 \%$ of the bees exited the nest properly using the ramp and were exposed to powder, but only about $50 \%$ returned to enter the lower tubes properly. The other half used the exit grooves to re-enter. Proper exit behavior and contact with the biocontrol product was by far the most important aspect of the dispenser. In the present study, the nests with $O$. cornifrons cocoons were placed in the study orchard approximately 2 weeks prior to immunomarking in order to allow for emergence, mating, and nest establishment prior to cherry bloom. Adult bees were observed foraging on weeds in the ground cover prior to cherry bloom.

\subsection{Marking of bees}

$O$. cornifrons adults were self-marked with chicken egg whites (Deb-El Foods Corporation, Elizabeth, NJ, USA). Egg white marker was placed in the grooves of the plexiglass plate $30 \mathrm{~h}$ prior to flower sample collection. Early bloom and the short exposure period was chosen to maximize the possibility of bees moving to fresh flowers, for flowers to be sampled before senescence, and to minimize secondary movement of the marker to new flowers by other pollinators such as honey bees and the few Andrenid bees that were present. Excluding night hours when the bees do not fly, flight was possible during the $19 \mathrm{~h}$ of daylight, but $3 \mathrm{~h}$ were below the $10{ }^{\circ} \mathrm{C}$ threshold for flight. Of the remaining $16 \mathrm{~h}$, wind speed above $10 \mathrm{~km} / \mathrm{h}$ with wind speed gusts of over $24 \mathrm{~km} / \mathrm{h}$ minimized flight for about $10 \mathrm{~h}$, so actual optimal foraging time before the flower samples were collected was approximately only $6 \mathrm{~h}$.

\subsection{Sample collection and handling}

Sampling points $(n=30)$ at different distances were randomly selected in three concentric zones $(15,35$, and
$55 \mathrm{~m}$ radius from the Osmia nest box) in the study orchard (Figure 2). The closest distance sampled was $4.95 \mathrm{~m}$ from the nest box. In each zone, ten randomly selected trees were sampled comprising single-tree replications. From each replicate tree we randomly collected 50 samples (five cherry blossoms/sample) totaling 250 blossoms per tree. Thus a total 1,500 samples (7,500 blossoms) (500 samples/concentric zone) were collected from 30 trees for analysis. In all samples, each blossom was individually plucked from trees with the help of a flat-tip straight forceps (made of stainless steel). Blossoms were randomly selected and were collected from the interior and exterior canopy of sample trees. Forceps were cleaned in alcohol $(70 \%)$ when moving to new trees and only the base of the flower was touched while collecting to avoid cross-contamination.

All samples of cherry blossoms were collected into plastic sample bags with mesh dividers (Agdia Inc., IN, USA), and were immediately placed in a cooler containing ice in field. These samples were brought to the laboratory and were kept in a $-80{ }^{\circ} \mathrm{C}$ storage facility (Thermo LabSystems, MA, USA). ELISA was used to determine the presence of protein marker chicken egg albumin (CEA).

\subsection{Laboratory assays}

Standardization of bioassays for O. cornifrons marked flowers was conducted in a set of preliminary laboratory studies, and the ELISA procedure (Jones et al. 2006; Hagler and Jones 2010) described below was optimized for extracting and quantifying the immunomarker from flower samples collected from cherry trees.

Extractions of CEA from cherry blossoms were performed with $10 \mathrm{~mL}$ of TBS with $1 \%$ EDTA at $27^{\circ} \mathrm{C}$ for $3 \mathrm{~min}$. Eighty microliters of sample were then transferred to ELISA plates (Plates, Nunc-Immuno Plate MaxiSorp Surface (NUNC Brand Products, A/S, Roskilde, Denmark)). All samples and controls were run in triplicate. Negative controls were prepared from unmarked cherry blossoms sampled from a control orchard. Incubation was done for $1 \mathrm{~h}$ at $37{ }^{\circ} \mathrm{C}$. Plates were washed $5 \times$ with PBST using a Dynex multi plate washer (Thermo LabSystems). Plates were blocked with $200 \mu \mathrm{L}$ of PBS-BSA (1\% BSA) at pH 7.4 (Sigma) and incubated overnight at $4{ }^{\circ} \mathrm{C}$. After blocking, plates were washed $5 \times$ with PBST. All reagents were prepared in 


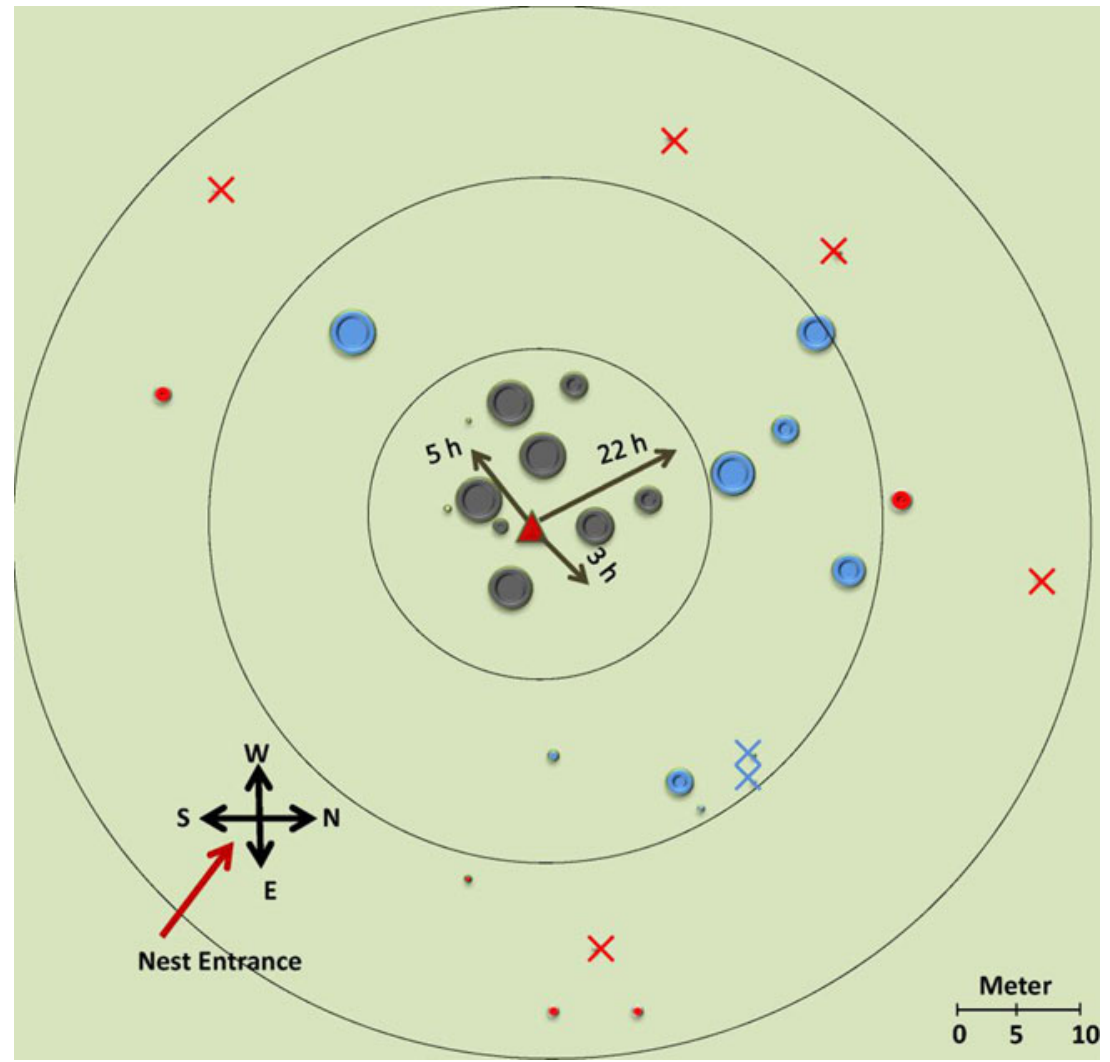

Figure 2. Map of the study area where red triangle is $O$. cornifrons nest dispenser box and circles represent sampled trees. Diameter of each circle represents protein marking (\%) found on that tree ranging from 0.01$100 \%$ and $X$ represents zero protein marking. Arrows indicate the wind direction and associated number is averaged duration of wind in that direction. Red arrow is showing the bee entrance direction. Sample points in dark gray, blue, and red color represent sampled trees in concentric zone of $15 \mathrm{~m}$ (inner), $35 \mathrm{~m}$ (middle), and $55 \mathrm{~m}$ (outer) radius, respectively from the nest box.

filtered double-distilled water (Thermo Nanopure system). Anti-CEA prepared in rabbit at 1:8,000 dilution (Sigma No.C-6534) prepared in PBS-BSA (1 \%)+1.3 ppm Silwet $\mathrm{L} 77(1.3 \mu \mathrm{L} / \mathrm{mL})$ was added per well and incubated for $1 \mathrm{~h}$ at $37^{\circ} \mathrm{C}$. Plates were washed $5 \times$ with PBST. Goat anti-rabbit IgG (Sigma No. A-6154) conjugated to hydrogen peroxidase prepared 1:12,000 dilution in PBSBSA $(1 \%)+(1.3 \mu \mathrm{L} / \mathrm{mL}) 80 \mu \mathrm{l}$ per well was added and incubated for $2 \mathrm{~h}$ at $37^{\circ} \mathrm{C}$. Plates were washed $5 \times$ with PBST. Eighty microliters per well of substrate (TMB Substrate) were incubated at 15 and $30 \mathrm{~min}$ and read with microplate reader (Multiskan Ascent, Thermo Labsystems) at $650 \mathrm{~nm}$. Blossom samples were considered marked when the absorbance reading was twice the negative check.

\subsection{Horticultural measurements in study orchard}

\subsubsection{Measurement of percent bloom}

Estimates of percent bloom were determined at the time of immunomarked $O$. cornifrons release as well as at the time of flower sample collection. Percent bloom on the day of release of immunomarked $O$. cornifrons was determined by counting fully opened flowers and 
flower buds until $n=100$ was reached and then calculating the proportion of fully opened flowers on five randomly selected limbs of all 30 sample trees. Similarly, percent bloom at the time of flower collection was calculated from all trees in the same manner.

\subsubsection{Fruit density measurement in the study orchard}

The fruit density per limb cross-sectional area $\left(\mathrm{cm}^{2}\right)$ of sample trees in the study orchard was compared with sample trees $(n=30)$ of a control orchard block at the time of fruit harvest. Sample trees in control orchards were randomly selected from all directions from the center and in similar concentric zones as study orchard. At that time, three limbs were randomly selected from each sample tree, the total number of fruit per limb was counted and the limb cross-sectional area was measured (Schupp and Greene 2002). Limb cross-sectional area and fruit density were determined as follows:

Limb cross-sectional area $=\frac{(\text { Limb circumference })^{2}}{4 \pi}$

Fruit density $=\frac{\text { Total number of fruits }}{\text { Limb cross-sectional area }\left(\mathrm{cm}^{2}\right)}(2)$

\subsection{Statistical analysis}

The relationship between distance from the point of release (i.e., nest box) of $O$. cornifrons and the proportion of immunomarked cherry flower samples collected from different sampling points (i.e., cherry tree) was determined by using a linear regression analysis. This regression analysis was also used to analyze the data related to the percent bloom at the time of sample collection and distance from the nest box. A polynomial regression analysis (SigmaPlot ${ }^{\circledR}$ 11, Systat Software, Inc., Chicago, IL) determined the relation between the distance of sample trees from the nest box and the fruit density per limb cross-sectional area $\left(\mathrm{cm}^{2}\right)$. A linear regression analysis was used to determine the relation between fruit density per limb cross-sectional area $\left(\mathrm{cm}^{2}\right)$ and the proportion of protein marked samples. A $t$ test compared fruit density per limb cross-sectional area $\left(\mathrm{cm}^{2}\right)$ of study orchard and control orchard block.

\section{RESULTS}

\subsection{Foraging of $O$. cornifrons in cherry orchard at the time of bloom}

Percent bloom at the time of sample collection was evenly distributed throughout the study orchard and did not show any significant relationship with distance from $O$. cornifrons nest box $\left(P=0.42, R^{2}=0.024\right.$, slope $=0.038$, intercept $=6.76)$. During the study, the average wind direction was northwest for $22 \mathrm{~h}$ of the $30-\mathrm{h}$ foraging period (Figure 2).

The proportion of protein marking decreased with increasing distance from $O$. cornifrons nest box (illustrated by circles whose diameter corresponds to the proportion of protein marking in Figure 2). Trees at the medium distance (16-35 $\mathrm{m}$ radius) from the nest box of $O$. cornifrons showed greatest variability in protein marking (Figure 2). The proportion of proteinmarked flowers from trees at increasing distances from the nest linearly decreases $\left(R^{2}=\right.$ 0.35 , slope $=1.52$, intercept $=80.38, P=0.0006$; Figure 3). There was a sharp decrease in the proportion of protein markings beyond $35 \mathrm{~m}$ from the nest box (Figure 3).

\subsection{Relationship between distance from nest box, proportion of immunomarked flower samples, and fruit density}

There was no statistically significant declining trend $\left(P=0.20, R^{2}=0.11\right)$ in the mean fruit density (in terms of mean number of fruit per limb crosssectional area) with increasing distance from $O$. cornifrons nest box (Figure 4). There was no trend in average fruit density within $40 \mathrm{~m}$ from $O$. cornifrons nest box; however, a decline in fruit density after $40 \mathrm{~m}$ from Osmia nest box was recorded (Figure 4). The mean fruit density of sampled trees in the study orchard did not show 


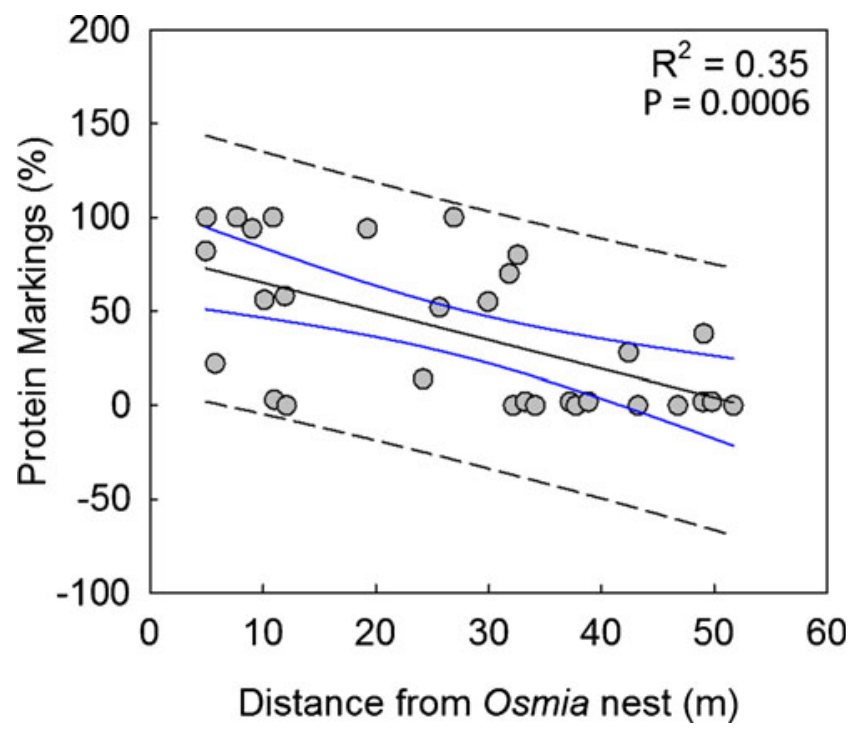

Figure 3. Foraging of $O$. cornifrons as quantified from the proportion of protein marking in flower samples collected from 30 trees (sampling points) at different distances within a 55-m radius area from O. cornifrons nest placed at the center of a commercial tart cherry orchard in Adams County, Pennsylvania. Inner solid lines represent mean and $95 \%$ confidence interval and the outer dashed lines represent the prediction band.

any trend with proportion of protein markings on sampling distance point $\left(R^{2}=0.02\right.$, intercept $=$ sampled flowers from sampling trees at each 57.65 , slope $=0.076, P=0.42$ ).

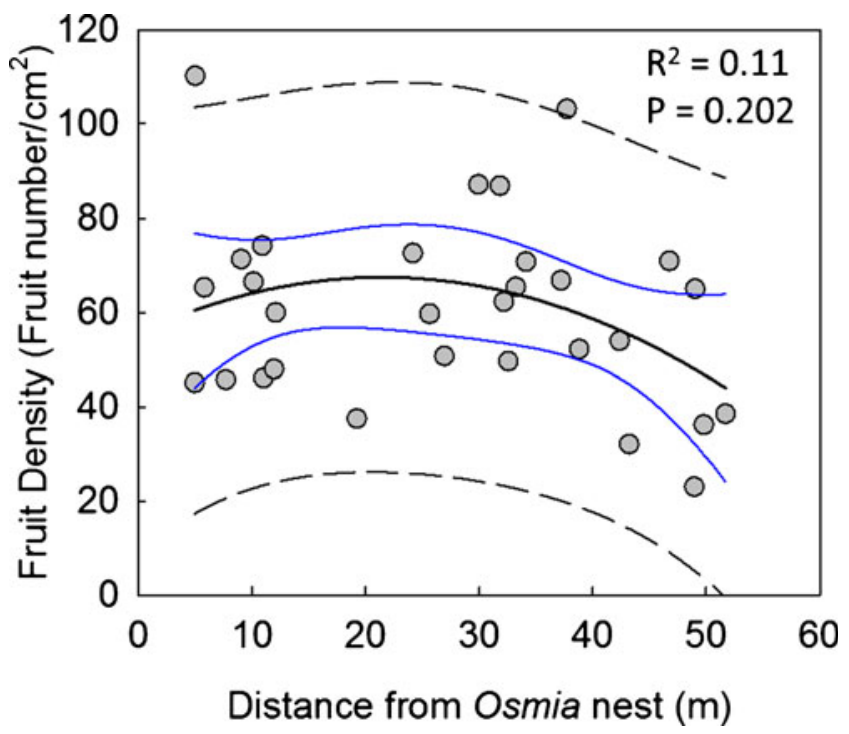

Figure 4. Relationship between the mean fruit density [number of fruits/limb cross-sectional area $\left(\mathrm{cm}^{2}\right)$ ] and different distances (sampling points) within $55 \mathrm{~m}$ radius area from $O$. cornifrons nest box. Inner solid lines represent mean and $95 \%$ confidence interval and the outer dashed lines represent the prediction band. 


\subsection{Fruit yield in $O$. cornifrons pollinated orchard and control orchard block}

The study orchard with the $O$. cornifrons nest box showed significantly greater fruit density on the trees that were sampled for protein marking (mean $=60.57$ fruits $/ \mathrm{cm}^{2}$ of tree limb, $\mathrm{SD}=19.89, P=0.000, t=7.146, n=30$ trees) than the control orchard block without $O$. cornifrons nest (mean $=29.11$ fruits $/ \mathrm{cm}^{2}$ of tree limb, $\mathrm{SD}=$ $13.63, n=30$ trees).

\section{DISCUSSION}

The results of this study showed that the foraging range and behavior of $O$. cornifrons adults in a cherry orchard can be quantified by using an immunomarker. In a manner similar to studies which have successfully used Osmia sp. as a vector to disperse bacterial biological control agents of fire blight (Biddinger et al. 2009a, 2010; Maccagnani et al. 2006), $O$. cornifrons adults were able to acquire the fine egg white particles on their bodies and disperse these particles to cherry flowers at levels high enough to be detected. Wind direction appears to influence the distribution pattern of immunomarking in this study. Wind plays a crucial role in the dispersal of insects in field environment (Schneider 1962), especially for a relatively small-bodied bee attempting to return to a nest flying into a stiff wind. Though, in our study, the $O$. cornifrons nest was sheltered from the wind with a plastic shelter from all directions except the front (facing southeast), that wind direction and speed affect the foraging behavior of $O$. cornifrons in an orchard is evident from the majority of the marked blossoms being detected downwind from the nest box (Figure 2). Average wind duration for $\mathrm{N}-\mathrm{W}$ direction was $22 \mathrm{~h}$ of the 30-h foraging period with most of the foraging taking place in the $4 \mathrm{~h}$ that wind speed was below $10 \mathrm{kmh}$. Therefore, effect of wind speed and direction on $O$. cornifrons dispersal as quantified in terms of the proportion of immunomarker found in the flower samples in field environment needs further investigation.

Our results suggest that the protein marking decreased with increasing distance from $O$. cornifrons nest box (Figure 2). Results from the marked bloom samples show a decline in fruit yield at those same distances after $40 \mathrm{~m}$ and indicate the effective foraging range of approximately $500 \mathrm{O}$. cornifrons females in a commercial tart cherry orchard to be about 35 $40 \mathrm{~m}$ under the relatively short foraging period allowed in this experiment and under the relatively cool, windy conditions that prevailed. This range estimate correlates well with visual observations made for $O$. cornifrons in Japanese apple orchards of 40-60 m from the nests, as well as the recommendation to place nests $100 \mathrm{~m}$ apart (Yamada et al. 1971; Maeta and Kitamura 1974). Several other methods of studying dispersal tend to overestimate foraging distances, but the immunomarking method may underestimate them, as the number of flowers visited in a foraging bout increases, the amount of immunomarking on the bee's body will decrease. So these bees may visit other flowers in the study orchard beyond $35-55 \mathrm{~m}$, while no longer depositing immunomarking powder. However, this immunomarking dilution effect needs further investigations.

The slightly lower foraging range we found compared to the Japanese studies may be due to the limited foraging time we allowed our bees during this study compared to the entire bloom period for the Japanese studies or due to differences in cherry and apple as a crop. Such short range foraging of $O$. cornifrons in cherry orchard could be due to the presence of more blossoms per tree than other fruit trees such as apple. In general, Osmia bees may fly long distances while foraging, but when sufficient pollen resources/host flowers are present near their nesting sites (such as in this study) they may prefer foraging close to their nesting sites instead of flying longer distances (Zurbuchen et al. 2010, Radmacher and Strohm 2010). Besides number of blossoms on a tree, differences between the aforementioned studies could be due to tree planting/density and bee shelter location within the orchards.

In previous studies, foraging distance was estimated by calculating homing ranges, the maximum distance from the nest that a bee can find its way home. However, this overestimates 
foraging range. Greenleaf et al. (2007) reviewed 96 published records for 62 bee species that evaluated maximum foraging/homing distances, and found a highly significant positive relationship between the bee body size and various methods of measuring homing/foraging limits. Foraging range for a bee, however, is dependent on multiple factors such as the spatial and temporal distribution and availability of resources during its life cycle. For example, while the homing range of O. cornuta (Latreille) was estimated at $1,800 \mathrm{~m}$, when placed in an orchard during peak bloom with abundant floral resources, most females forage within 100-200 $\mathrm{m}$ of their nests (Vincens and Bosch 2000). The homing range of the smaller $O$. cornifrons (Radoszkowksi) in Japanese apple orchards was likewise found to be approximately $500 \mathrm{~m}$, but likewise, its effective pollination range in large orchards was estimated to be only 40 to $60 \mathrm{~m}$ from the nesting site (Maeta and Kitamura 1974; Kitamura and Maeta 1969; Guedot et al. 2009). The foraging ranges of several stingless bee species have likewise been shown to be approximately $300 \mathrm{~m}$ shorter than their homing distance (van Nieuwstadt and Ruano Iraheta 1996).

The $O$. cornifrons nest box remained in the orchard throughout the 7-day bloom period thus the yield data should have been an estimate of the full pollination potential of that nest beyond the 30 -h test period. Our study found the number of cherries per limb cross-sectional area to be over twice as high on trees in the Osmia test orchard than in a control orchard very similar in age, size, and management and where equivalent levels of honey bees were present. While comparing these two orchard blocks, any minor differences between blocks should have been minimized by the horticultural method of relating fruit number to the scaffold limb cross-sectional area (Schupp and Greene 2002). This control block was isolated by distance from habitat containing wild populations of $O$. cornifrons and none had been released, so the effects on fruit number is directly attributable to the additive effect of having $O$. cornifrons supplementing the level provided by honey bees alone. Similarly, a related species, Osmia lignaria Say doubled cherry yields in Utah over a 5-year period over that of $A$. mellifera Utah (Bosch and
Kemp 2006). They attributed this to shorter foraging range that forced it to concentrate on fruit trees within the targeted orchard, a greater fidelity to fruit trees when foraging, longer foraging period due to its lower light and temperature thresholds, and in its greater effectiveness in transferring pollen (Torchio 1981; Kuhn and Ambrose 1984).

Other factors contributing to higher fruit density (yield) in the study orchard could be the abundance of additional native pollinators, but net collections of bees in both the test and control orchard during bloom found that while honey bee numbers were fairly abundant and similar in both blocks, solitary bees and bumble bees were not found in the areas sampled of either cherry block.

This study demonstrates an immunomarking method to mark bees and quantify where they have been by measuring the residues they leave on flowers is viable and a powerful tool in understanding the foraging behavior and limits of bees. Our data based on the marking and yield data suggest that the effective pollination range of 500 $O$. cornifrons females from a single nest box is only about $40 \mathrm{~m}$ rather than the $500 \mathrm{~m}$ estimate based on homing range. This translates into an effective foraging/pollinating area of slightly more than 0.5 ha for each nest and we would recommend placing nests at a slightly closer range of $80 \mathrm{~m}$ apart rather than $100 \mathrm{~m}$ apart as recommended for apple pollination currently in Japan. Future research into optimizing release rates of female $O$. cornifrons in nests may find the optimal number of bees needed for commercial pollination of various fruit crops in the eastern USA. This number may vary by crop. For example, since tart cherry needs $20-75 \%$ of flowers set for a commercial crop and has more flowers per tree than apple, which needs only $2-8 \%$ set, the number of Osmia necessary for pollination might be much higher in cherry (Chaplin and Westwood 1980).

\section{ACKNOWLEDGMENTS}

The authors sincerely thank the USDA NIFA for a SCRI grant on sustainable fruit pollination (PEN04398) and the State Horticultural Association of Pennsylvania for their financial support of this study. The authors also thank Kathy Wholaver, Edwin Winzeler, Amanda Ritz, 
Maryann Frazier, and numerous summer interns/assistants for their help in conducting this study, Doug Lott for the use of the commercial orchard, and several anonymous reviewers for their constructive comments on a previous draft of this manuscript.

Technique d'immunomarquage pour déterminer les modes d'approvisionnement d'Osmia cornifrons et la production de fruits en résultant, dans un verger de cerisiers

Technique de marquage / approvisionnement / processus d'auto-marquage / pollinisation/ guêpe maçonne / pollinisateur

Eine Immuno-Markierungsmethode zur Bestimmung des Sammelverhaltens von Osmia cornifrons und der daraus resultierende Fruchtansatz in einer Kirschplantage

Immunomarkierzng / Sammelverhalten / Osmia cornifrons / Selbst-Markierung / Bestäubung / Bestäuber

\section{REFERENCES}

Akey, D.H., Hayes, J.L., Fleischer, S.J. (1991) Use of elemental markers in the study of arthropod movement and trophic interactions. Southwest. Entomol Suppl. 14, 1-87

Batra, S.W.T. (1979) Osmia cornifrons and Pithitis smaragdula, two Asian bees introduced into the United States for crop pollination. Maryland Agricultural Experiment Station, Special Miscellaneous Publication 1, 307-312

Batra, S.W.T. (1998) Hornfaced bees for apple pollination. Am. Bee J. 138, 364-365

Biddinger, D.J., Mullin, C., Frazier, J., Frazier, M., Ashcraft, S., Rajotte, E. (2011a) Assessing the pesticide susceptibility of native bees in Pennsylvania orchards. Penn Fruit News 91, 49-55

Biddinger, D., Rajotte, E., Joshi, N., Ritz, A. (2011b) Wild bees as alternative pollinators. Fruit Times 30, 1-4

Biddinger, D.J., Ngugi, H., Frazier, J., Frazier, M., Leslie, T., Donovall, L.R. (2010) Development of the mason bee, Osmia cornifrons, as an alternative pollinator to honey bees and as a targeted delivery system for biological control agents in the management of fire blight. Penn Fruit News 90, 35-44

Biddinger, D., Frazier, J., Frazier, M., Rajotte, E., Donovall, L., Leslie, T. (2009a) Solitary bees as alternative pollinators in Pennsylvania fruit crops. Penn Fruit News 89, 84-94

Biddinger, D.J., Ngugi, H., Frazier, J. (2009b) Development of the mason bee, Osmia cornifrons, as a targeted delivery system for biocontrol agents in the management of fire blight. Penn Fruit News 89, 95-100

Blackmer, J.L., Hagler, J.R., Simmons, G.S., Canas, L.A. (2004) Comparative dispersal of Homalodisca coagulata and Homalodisca liturata (Homoptera: Cicadellidae). Environ. Entomol. 33, 88-99

Blackmer, J.L., Hagler, J.R., Simmons, G.S., Henneberry, T.J. (2006) Dispersal of Homalodisca vitripennis (Homoptera: Cicadellidae) from a point release site in citrus. Environ. Entomol. 35, 1617-1625

Bosch, J., Kemp, W.P. (2002) Developing and establishing bee species as crop pollinators: the example of Osmia spp. (Hymenoptera: Megachilidae) and fruit trees. Bull. Entomol. Res. 92, 3-16

Bosch, J., Kemp, W.P. (2006) Bee population returns and cherry yields in an orchard pollinated with Osmia lignaria (Hymenoptera: Megachilidae). J. Econ. Entomol. 99, 408-413

Bosch, J., Kemp, W., Trostle, G. (2006) Bee population returns and cherry yields in an orchard pollinated with Osmia lignaria (Hymenoptera: Megachilidae). J. Econ. Entomol. 99, 408-413

Bosch, J., Sgolastra, F., Kemp, W.P. (2008) Life cycle ecophysiology of Osmia mason bees used as crop pollinators, pp. 83-103. In R. R. James and T. L. Pitts-Singer [eds.], Bee pollination in agricultural ecosystems. Oxford University Press, New York.

Buczkowski, G., Bennett, G. (2006) Dispersed centralplace foraging in the polydomous odorous house ant, Tapinoma sessile as revealed by a protein marker. Insectes Soc. 53, 282-290

Chaplin, M.H., Westwood, M.N. (1980) Relationship of nutritional factors to fruit set. J. Plant Nutr. 2, 477-505

Gathmann, A., Tscharntke, T. (2002) Foraging ranges of solitary bees. J. Anim. Ecol. 71, 757-764

Greenleaf, S.S., Williams, N.M., Winfree, R., Kremen, C. (2007) Bee foraging ranges and their relationship to body size. Oecologia 153, 589-596

Guedot, C., Bosch, J., Kemp, W.P. (2009) Relationship between body size and homing ability in the genus Osmia (Hymenoptera: Megachilidae). Ecol. Entomol. 34, 158-161

Hagler, J.R. (1997) Field retention of a novel mark-releaserecapture method. Environ. Entomol. 26, 1079-8

Hagler, J.R., Jackson, C.G. (1998) An immunomarking technique for labeling minute parasitoids. Environ. Entomol. 27, 1010-16

Hagler, J.R., Jones, V.P. (2010) A protein-based approach to mark arthropods for mark-capture type research. Entomol. Exp. Appl. 135, 177-192

Hagler, J.R., Naranjo, S.E. (2004) A multiple ELISA system for simultaneously monitoring intercrop movement and feeding activity of mass-released insect predators. Int. J. Pest Manag. 50, 199-207

Hagler, J.R., Cohen, A.C., Dradley-Dunlop, D., Enriquez, F.J. (1992) New approach to mark insects for feeding and dispersal studies. Environ. Entomol. 21, 20-25 
Hagler, J., Mueller, S., Teuber, L.R., Van Deynze, A., Martin, J. (2011a) A method for distinctly marking honey bees, Apis mellifera, originating from multiple apiary locations. J. Insect Sci. 11:143 available online: insectscience.org/11.143

Hagler, J.R., Mueller, S., Teuber, L.R., Machtley, S.A., Van Deynze, A. (2011b) Foraging range of honey bees, Apis mellifera, in alfalfa seed production fields. J. Insect Sci. 11:144 available online: insectscience.org/11.144

Jones, V.P., Hagler, J.R., Brunner, J.F., Baker, C.C., Wilburn, T.D. (2006) An inexpensive immunomarking technique for studying movement patterns of naturally occurring insect populations. Environ. Entomol. 35, 827-836

Joshi, N. K., Biddinger, D., Rajotte E.G. (2011) A survey of apple pollination practices, knowledge and attitudes of fruit growers in Pennsylvania. 10th International Pollination Symposium, Puebla, Mexico.

Kitamura, T., Maeta, Y. (1969) Studies on the pollination of apple by Osmia: (III) Preliminary report on the homing ability of Osmia cornifrons (Radoszkowski) and $O$. pedicornis Cockerell. Kontyu 37, 83-90

Kuhn, E.D., Ambrose, J.T. (1984) Pollination of 'Delicious' apple by megachilid bees of the genus Osmia (Hymenoptera: Megachilidae). J. Kans. Entomol. Soc. 57, 169-180

Maccagnani, B., Ladurner, E., Santi, F., Burgio, G. (2003) Osmia cornuta (Hymenoptera, Megachilidae) as a pollinator of pear (Pyrus communis): Fruit- and seedset. Apidologie 34, 207-216

Maccagnani, B., Bazzi, C., Biondi, E., Tesoriero, D., Maini, S. (2006) Potential of Osmia cornuta as a carrier of antagonistic bacteria in biological control of fire blight: a comparison with Apis mellifera. Acta Hortic. 704, 379-386

Mader, E., Spivak, M., Evans, E. (2010) Managing alternative pollinators: a handbook for beekeepers, growers and conservationists. Sustainable Natural Resource and Education Program handbook; 11, NRAES Cooperative Extension, Ithaca, NY. 162 pp.

Maeta, Y. (1990) Utilization of wild bees. Farming Japan 24, 13-22

Maeta, Y. (1978) Comparative studies on the biology of the bees of the genus Osmia of Japan, with special reference to their managements for pollinations of crops (Hymenoptera: Megachilidae). Tohoku National Agricultural Experiment Station. Bulletin No. 57, 221

Maeta, Y., Kitamura, T. (1974) How to manage the Mameko bachi, Osmia cornifrons (Radodoskowski), for pollination of fruit crops. Co. Ltd., Ask. 28 p

Monzon, V.H., Bosch, J., Retana, J. (2004) Foraging behavior and pollinating effectiveness of Osmia cornuta and Apis mellifera (Hymenoptera: Megachilidae, Apidae) on 'Comice' pear. Apidologie 35, 575-585 van Nieuwstadt, M.G.L., Ruano Iraheta, C.E. (1996) Relation between size and foraging range in stingless bees (Apidae, Meliponinae). Apidologie 27, 219-228

Radmacher, S., Strohm, E. (2010) Factors affecting offspring body size in the solitary bee Osmia bicornis (Hymenoptera, Megachilidae). Apidologie 41, 169177

Ritz, A., Biddinger, D., Rajotte, E., Sahli, H., Joshi, N. (2012) Quantifying the efficacy of native bees for orchard pollination in Pennsylvania to offset the increased cost and decreased reliability of honey bees. Penn Fruit News 92, 6-66

Schneider, F. (1962) Dispersal and migration. Ann. Rev. Entomol. 7, 223-242

Schupp, J.R., Greene, D.W. (2002) Thinning Mcintosh apple trees with blossom thinners, with and without postbloom NAA: A report to the New England Tree Fruit Growers Research Committee. Fruit Notes 67, 9-12

Sekita, N., Watanabe, T., Yamada, M. (1996) Population ecology of Osmia cornifrons (Hymenoptera, Megachilidae) in natural habitats. Bulletin of the Aomori Apple Experiment Station 29, 17-36

Sekita, N., Yamada, M. (1993) Use of Osmia cornifrons (Radoszkowski) for pollination of apples in Aomori Prefecture, Japan. JARQ Japan Agricultural Research Quarterly 26, 264-270

Torchio, P.F. (1981) Field experiments with Osmia lignaria propinqua Cresson as a pollinator in almond orchards: II, 1976 studies (Hymenoptera: Megachilidae). J. Kans. Entomol. Soc. 54, 824-836

Vincens, N., Bosch, J. (2000) Nest site orientation and relocation of populations of the orchard pollinator Osmia cornuta (Hymenoptera: Megachilidae). Environ. Entomol. 29, 69-75

Xu, H.-L., Yang, L.-I., Kwon, Y.J. (1995) Current status on the utilization of Osmia bees as pollinators of fruit trees in China (Hymenoptera: Megachilidae). Korean J. Apiculture 10, 111-116

Yamada, M., Kawashima, K., Aizu, H. (1984) Population dynamics of the horn faced bee, Osmia cornifrons Radoszkowski, with a special reference to the population management. Bulletin of the Aomori Apple Experiment Station 21, 23-92

Yamada, Y., Oyama, N., Sekita, N., Shirasaki, S., Tsugawa, C. (1971) The ecology of the megachilid bee Osmia cornifrons and its utilization for apple pollination [In Japanese]. Bulletin of the Aomori Apple Experiment Station 26, 39-77

Zurbuchen, A., Landert, L., Klaiber, J., Müller, A., Hein, S., Dorn, S. (2010) Maximum foraging ranges in solitary bees: only few individuals have the capability to cover long foraging distances. Biol. Cons. 143, 669-676 